\title{
Classroom Teacher Candidates' Comprehension Levels of Key Concepts of the Life Science Curriculum
}

\author{
Salih Akyıldız ${ }^{1}$, Taner Altun ${ }^{1}$, Şengül Kasım² \\ ${ }^{1}$ Fatih Faculty of Education, Trabzon University, Turkey \\ ${ }^{2}$ Institute of Education Sciences, Trabzon University, Turkey \\ Correspondence: Taner Altun, Trabzon University, Fatih Faculty of Education, Department of Primary Education, \\ 61300, Akcaabat, Trabzon, Turkey.
}

Received: June 11, 2018

doi:10.11114/jets.v6i9.3354
Accepted: July 9, $2018 \quad$ Online Published: July 23, 2018

URL: https://doi.org/10.11114/jets.v6i9.3354

\begin{abstract}
This study aims to investigate the comprehension levels of classroom teacher candidates about the key concepts of Life Science Curriculum. The study was carried out within the qualitative research approach and descriptive survey model was adopted. The sample of study consists of final year 114 classroom teacher candidates who are studying Primary Teacher Education Program at two different Education Faculties in Turkey. As a result of analyzing the primary Life Science curriculum, 18 foundational concepts were identified. In order to determine teachers' comprehension levels and conceptual misconceptions about these concepts, "concept definition form" consisting of short answer and open ended semi-structured questions prepared by researchers was used. The data obtained by the application of this form have been analysed through descriptive analysis method. The answers in the explanation section of the concept description form were evaluated in five categories as "comprehension", "partial comprehension", "incomprehension", "miscomprehension" and "no response". According to the findings obtained in the study, it was concluded that teacher candidates understand some of the concepts in the Life Science curriculum at a "good" level, mostly understand at "partially" level, "incomprehension" some concepts or have "miscomprehension". In order to increase curriculum literacy, it is suggested that the primary teacher candidates should be given training about the main concepts related to the Life Science curriculum.
\end{abstract}

Keywords: curriculum literacy, life science curriculum, primary teacher candidates

\section{Introduction}

As it is known, teachers have a critical role in the implementation of curriculum Teachers decide that students should act in such a way as to enable them to learn the learning content, the activities and the teaching curriculum effectively (Stabback, 2016). When curricula are changed, the implementation of new curricula requires that teachers have knowledge of the new concepts. When implementing the curriculum, teachers face a number of obstacles such as difficult classroom conditions, inappropriate school environment, and resource shortage (Fullan, 2007). These factors, which can limit curriculum innovation, are related to both the teacher and the context in which innovation takes place (Bennie and Newstead, 1999). Teachers' inability to understand the curriculum completely is one of the factors that can limit their curriculum implementation.

The curriculum is a tool which teachers often use to organize teaching and facilitate learning for students (Penuel, Phillips, and Harris, 2014). In general, the curriculum refers to "the flow of a work or formation", whereas in education the curriculum refers to "learned or taught" (Karakaya, 2001). In terms of education, the curriculum refers "all learning activities planned and guided by the school (Büyükkaragöz, 1997). The teaching curriculum is to arrange the topics of the course in accordance with the aims and principles of the school type, taking into consideration the time and duration of the subjects at certain levels of education (Varış, 1996). Curriculum consists of the determination of objectives, content, learning-teaching process and evaluation components. Although their functions do not change, the "aims and objectives" component of the curriculum is also referred to as acquisition, "content" component refers to theme-learning area and "teaching-learning process" component refers to "activities" (Akpınar, 2011). Curricula are developed by creating relationships between these main components. 
Any teaching institution cannot exist without a curriculum. Along with the importance of formal education, the curriculum has become dynamic due to changes in our society (Alvior, 2015). Curriculum guides the teacher's lessons and offer ideas and strategies to teachers to assess students' progress. Without the guidance of the curriculum, teachers cannot be sure that they provide the knowledge and opportunities needed for student achievement. The teacher serves as mediator between the curriculum and the student. However, no matter how well a curriculum is prepared, there is no validity of the curriculum if it cannot be applied well.

Clark, Klein and Burks (1972) described the teacher; as "the person who is the curriculum developer, who finds and develops curriculum materials, reveals the ways of reaching the aims, initiates and tries to make changes in the class" (cited in Yüksel, 1998). Without the teachers, the curriculum cannot be implemented. Successful implementation of the curriculum depends on teachers' adoption of the curriculum philosophy and positive attitudes toward the curriculum. Teachers can interpret, adapt and even transform curriculum implementations according to their own beliefs (Stein and Coburn, 2008). The effectiveness of a curriculum depends largely on the practicing teachers' interpretation and practice skills (Fidan, 1985). In other words, teachers are expected to be "curriculum literate".

Curriculum literacy requires that the teacher has knowledge of the process of developing, implementing, and evaluating the curriculum. Shulman (1987) regarded curriculum knowledge as one of the knowledge that teachers should acquire. The Turkish Ministry of National Education (MoNE) showed the curriculum knowledge among the general qualifications of the teaching profession and developed competency areas such as "knowledge of curriculum", "application skills", "monitoring curriculum", "evaluation" and "development" for teachers (MEB, 2017). In order for teachers to be curriculum literate, they must first have the knowledge of the curriculum to understand correctly the basic concepts in the curriculum and to establish clear relations between the concepts.

Concepts are generally defined as mental imagery that occurs on an event, an attribute, or a quantity. In the Turkish Language Association's dictionary, the term "concept" as a term of education is defined as; "a general design that covers the common features of objects or events and collects them under a common name, a single object (individual concept) or a combination of objects that defines the essence of a class of objects (general concept), or a combination of attributes or special indications" (TDK, 2016). Concepts are mental tools that enable us to think, to understand the physical and social world and to communicate meaningfully (Senemoğlu, 2005). Concepts embody information about the world and show what characteristics this information have (Murphy, 2002). The concept functions as a building block of thought and used as a basic material in the identification and interpretation of reality (Demir and Acar, 1992). By means of concepts, people can understand and interpret what something is (Altunya, 2003). Similarly, people continue to construct concepts in everyday life to make sense of the world, people, and events (Marsh, 2009).

In certain fields of science, certain professions have specific concepts. Those who receive special education in that area and those who work for a long time, can use these concepts conformably and correctly (Güleryüz, 2013). Similarly, a curriculum has a structure that shows its own concepts and relationships between them. It is stated that there is a common consensus on the field of curriculum development compared to other fields, although a complete consensus on what the basic concepts are in different areas is not available (Marsh, 2009). Teachers who are responsible for implementing the curriculum expected to know these concepts well so that they can understand the curriculum. Otherwise, deficiencies in conceptual knowledge may also damage the teachers' beliefs about the curriculum.

One of the situations that prevent comprehension of knowledge or cause miscomprehension in a field of science is misconceptions. Misconceptions are ideas that are accepted by scientists and are different from their actual meanings (Nakhleh, 1992). Since concepts are abstract thoughts, concrete emphasis should be given to their teaching. For this purpose, different teaching materials to be used in concept teaching can be developed. It is known that learning through hands-on activities and using audio-visual techniques have positive effects in comprehension and remembering the topic (Lawson, Thomson, 1988, cited in., Ilbi, 2006). According to Baki (1999), misconceptions arise as a result of students' false beliefs and experiences. Misconceptions can conflict with scientific knowledge, create alternative beliefs in the person, and as a result they can lead to misinterpretation and misapplication.

Knowledge of what constitutes the basic building blocks of an individual's cognitive structure and which is at the core of all thinking skills is important in terms of achieving meaningful and lasting learning (Malatyalı and Yılmaz, 2010, p.321). When the success of the curriculum implementation is thought to be directly related to the teachers, the teacher candidates who are educated in the education faculties should know the concepts in the curriculum well enough to be able to use the concepts easily because they can change depending on the level of comprehension the knowledge, interpretations and usage of the basic concepts in the curriculum. As newly learned knowledge is associated with the previously acquired knowledge for comprehension, prior knowledge needs to be accurate. In other words, the cognitive structures of the teacher candidates should be organized correctly because the cognitive structures, i.e., the preliminary 
knowledge, will have an effect on the comprehending the curriculum that is because deficient and inadequate learning about concepts, may lead to partial comprehension or miscomprehension about the subject.

When we look at the studies in the field, it can be seen that there are some studies carried out aiming to determine the misconceptions about the teachers', teacher candidates and students' misconceptions in specific subject courses. Apart from a few limited studies (Akpınar and November 2016, Arık, 2006, Demirbilek, 2015, Üzemur 2013, Üztemur and Metin, 2015) on misconceptions in the area of measurement and evaluation, it has been understood that no study has been conducted on the level of teacher or teacher candidates' comprehension the basic concepts of the educational sciences within the scope of the curriculum. For this reason, it is thought that a carrying out a research about the level of comprehension the basic concepts of teacher candidates in Life Science would be an original study. In addition, in this study it is assumed that the findings of classroom teacher candidates' comprehension the basic concepts in the Life Science curriculum will contribute to the planning of activities for curriculum introductions on the one hand and to the more effective regulation of learning processes on concept teaching in education faculties on the other hand.

The fact that a teacher has conceptual misconceptions about the concepts of the purpose, content, educational situation and evaluation components of a curriculum may arise as a condition that prevents the comprehension and the implementation of the curriculum. The successful implementation of a curriculum is closely related to the fact that the teachers understand the teaching curriculum correctly. A good comprehension of a curriculum may only be possible with a good comprehension of the basic concepts within that curriculum. In this context, in which level the basic concepts of the Life Science curriculum which was accepted by the Head Council of Education and Morality and dated 15/07/2015 and numbered 70 and gradually implemented from 2016-2017 academic year is understood by classroom teacher candidates and the discovery of the misconceptions of the basic concepts in the context of the Life Science curriculum are considered as a matter worth researching. Therefore, in this study, it is aimed to investigate the comprehension levels of primary student teachers about the key concepts of Life Science Curriculum. In the study answers are sought to following questions:

1. How participant teachers describe the key concepts included in the Life Science Curriculum?

2. Do participant student teachers have any misconceptions about the key concepts of the Life Science Curriculum?

3. What is the level of participant teachers' curriculum literacy?

\section{Method}

\subsection{Research Model}

The current study was designed in a qualitative research approach and descriptive survey model was adopted in the study. The qualitative research approach is defined as "a research process in which qualitative data gathering methods such as observation, interview and document analysis are used and the perceptions and events are revealed in a realistic and holistic manner in a natural environment" (Yıldırım and Şimşek, 2011, p. 39). The case study method is a method that enables the investigator to enter into the subject and examine it in depth, allowing the case, event and situation to be examined thoroughly without prejudice (Ekiz, 2009, p. 46). In this study, in-depth examinations were made of the extent to which classroom teacher candidates could understand the concepts in the primary Life Science curriculum.

\subsection{The Study Group}

The study group consisted of fourth year primary teacher candidates who were studying at two different education faculties. Participants in the study were selected by employing appropriate sampling procedures. A total of 114 primary teacher candidates participated in the study. 27 (23.7\%) of the participants were female and 87 (76.3\%) of them were male.

\subsection{Data Collection Tools}

In the study, a short answered and open ended semi-structured question form, which composed of 18 questions, prepared by the researchers in order to determine the level of comprehension and misconceptions of the teacher candidates about the determined concepts was used for data collection. In terms of defining the concepts, the content of the Life Science curriculum was utilized. For this purpose, the Life Science curriculum has been examined and key concepts (see Table 1 below) which take place in curriculum development process are included in the Life Science teaching curriculum have been determined. It has been noted that the selected concepts consist of the basic concepts that are included in the discipline of a curriculum and which enable individuals to comprehend the Life Science curriculum. The prepared measurement instrument was presented to three faculty members who are experts in the field of Life Science curriculum. A question in the direction of the field experts was removed from the interview form, and a question was also corrected. A pilot interview was then held with 4 teachers to determine whether the questions were 
clear and understandable. As a result of the interview, it was understood that the questions were clear and understandable. As a result of this interview and the corrections made, it has been concluded that the data collection tool was valid and applicable.

Concepts that are included in the four basic components of a curriculum and that are expected to be understood by teacher candidates are presented in the following table:

Table 1. Components of a curriculum and related concepts

Components of Key Concepts
Curriculum

Curriculum

Aims-Objectives

Content

Learning-Teaching Process

Assessment

\author{
“aim", "student gaining", "knowledge acquisition", "attitude acquisition" \\ "content", "unit"
}

"readiness", "limited learning", "cognitive development", "affective development", "psycho-motor development", "individual difference" "performance"

"measurement", "evaluation", "formative assessment", “summative assessment"

Questions on the data collection form as an example: 1. What does aims-objectives mean? Please explain. 2. What does knowledge acquisition mean? Could you describe it please? Answers of teacher candidates were evaluated by using descriptive analysis according to the categories of "comprehension", "partial comprehension", "incomprehension", "miscomprehension", "not responding". The categories showing these levels of comprehension are described in detail below (Akbaş, 2008:75; Ekiz and Akbaş, 2005:61-78):

1. Comprehension: It contains the answers to all the aspects of the scientific answer about the question.

2. Partial Comprehension: Includes answers that include one or more directions of the current scientific answer but do not include all aspects.

3. Incomprehension: Repeating the question, answers that are unrelated or unclear are in this category.

4. Miscomprehension (misconception): Student answers that are alternative to the current scientific answers are collected in this category. Student responses in this category can vary widely and often include different student ideas that do not fit into the scientific realities.

5. Not responding: Empty answers or answers such as "I do not know" or "I forgot" are collected in this category.

\subsection{Data Collection and Analysis Procedures}

The prepared questionnaire was distributed to the participants at a time when they were suitable, and sufficient time was given to fill in the forms. The data obtained from open-ended questions, were analysed by employing descriptive analysis technique. In descriptive analysis, the aim is to present the findings to the reader in an organized and interpreted way. In descriptive analysis, direct quotations are given in appropriate places in order to reflect the views of individuals in a striking way (Yıldırım and Şimşek, 2011, p.224). In the descriptive analysis technique, data are summarized and interpreted according to previously determined categories. In this study data obtained are presented as frequency and percentage, and in the presentation of the findings, direct quotations were made from the views of the participants.

\section{Results}

In this section responds of teacher candidates are analysed and presented under "comprehension", "partial comprehension", "incomprehension", "miscomprehension" and "no response" categories. Findings are presented in frequencies and percentages.

\subsection{Comprehension Levels of Candidate Teachers About the Concepts of "Aims and Objectives" Component of the Curriculum}

Under this category student teachers were asked a question to explain the concepts "aim", "student gaining", "knowledge acquisition" and "attitude acquisition" and results are presented in Table 2 below:

Table 2. Levels of teacher candidates' comprehension of the concepts of objectives dimension of the curriculum

\begin{tabular}{|c|c|c|c|c|c|c|c|c|c|c|}
\hline \multirow[t]{2}{*}{ Concepts } & \multicolumn{2}{|c|}{ Comprehension } & \multicolumn{2}{|c|}{$\begin{array}{c}\text { Partial } \\
\text { comprehension }\end{array}$} & \multicolumn{2}{|c|}{$\begin{array}{c}\text { Incomprehen } \\
\text { sion }\end{array}$} & \multicolumn{2}{|c|}{$\begin{array}{c}\begin{array}{c}\text { Mis-compreh } \\
\text { ension }\end{array} \\
\end{array}$} & \multicolumn{2}{|c|}{$\begin{array}{c}\text { No } \\
\text { response }\end{array}$} \\
\hline & $f$ & $\%$ & $f$ & $\%$ & $f$ & $\%$ & $f$ & $\%$ & $f$ & $\%$ \\
\hline 1. Aim & 21 & 18,4 & 45 & 39,4 & 31 & 27,1 & 9 & 7,8 & 8 & 7,0 \\
\hline 2. Student gaining & 49 & 42,9 & 32 & 28,0 & 22 & 19,2 & 4 & 3,5 & 7 & 6,1 \\
\hline 3. Knowledge acquisition & 28 & 24,5 & 46 & 40,3 & 18 & 15,7 & 3 & 2,6 & 19 & 16,6 \\
\hline 4. Attitude acquisition & 25 & 21,9 & 47 & 41,2 & 26 & 22,8 & - & - & 16 & 14,0 \\
\hline
\end{tabular}


In data collection form the first question was "Explain what "objectives" means in the Life Science curriculum?" $21(18.4 \%)$ of the respondents answered this question at the level of "comprehension". Some of the answers in this category as follows: "desired in the process", "the knowledge, skills and attitudes desired to be gained by the students at the end of the education process". As a result of the analysis made, it is seen that $39,4 \%$ of them responded with partial comprehension, $27,1 \%$ of them incomprehension and 7,8\% of them with miscomprehension. $7 \%$ of the teacher candidates cannot answer this question.

Examples of responses by participants at the level of "partial comprehension" include: "the reason for exhibiting behaviour", "the reason for our plan", "the reason for doing a job", "the justification for doing something", "foreseen reason", "what we are trying to accomplish", "what is being targeted", "gaining skills". Some of the responses of teacher candidates at the level of miscomprehension are: "behaviour change", "the most common method" and "the motivation to start".

Second concept under the category of "Aims and Objectives" was "student gaining". As a result of the analysis it was found that $42.9 \%$ of the participants responded in the level of comprehension, $28 \%$ of them with partial comprehension, $19.2 \%$ of them with incomprehension, and 3.5\% of them responded with miscomprehension. $6.1 \%$ of the teacher candidates did not answer the question. As an example of the answers given by the participants at the comprehension level; "Cognitive, emotional and psychomotor behaviours that need to be gained", "knowledge, skills and attitudes", "feelings, thoughts and behaviours acquired at the end of the lesson". Some of the answers given by teacher candidates at the level of miscomprehension are: "a subtitle of the subject", "steps that express the process".

In regard to the concept of "knowledge acquisition"; $40.3 \%$ of participants answered at the level of "partial comprehension", $24.5 \%$ at "comprehension", $15.7 \%$ of at "incomprehension" and $2.6 \%$ of them "miscomprehension". $16.6 \%$ of the teacher candidates could not answer this question. Examples of teacher candidates' responses at a partial level of comprehension include: "correcting our false information", "acquiring knowledge", "research and learn", "gaining theoretical knowledge", "learning something unknown", "use a knowledge", "learning, getting", "transferring a knowledge we accept correctly". Teacher candidates' responses at the level of comprehension are some of the following: "embracing knowledge", "gained knowledge", "confronting an unknown situation", "necessary situation for learning", "using knowledge".

In regard to the concept "attitude acquisition", $41.2 \%$ answered in the level of partial comprehension, $22.8 \%$ of them with incomprehension, $21.9 \%$ of them with comprehension, and $14 \%$ of the teacher candidates could not answer this question. Examples of teacher candidates' responses at a partial level of comprehension include: "generating ideas", "behaviour development", "interest or indifference to the lesson", "feeding the positive feeling", "emotion", "value", "gaining behaviour", "to value", "appearance of attitude in behaviours" and "having ideas in some way". Teacher candidates' answers at the level of comprehension are some of the following: "decision making", "being related to certain behaviours", "assessing the topic to be learned", "subjective preference", "pre-emotional gain", "controlling emotion and thought".

\subsection{Level of Comprehension of Concepts Related to Content Component of the Curriculum}

The second component of a curriculum is the content. The participants were asked to describe what is "content" and "unit"?. Results are presented in Table 3.

Table 3. Participants' comprehension levels of concepts related to content of the curriculum

\begin{tabular}{|c|c|c|c|c|c|c|c|c|c|c|}
\hline \multirow[t]{2}{*}{ Concepts } & \multicolumn{2}{|c|}{ Comprehension } & \multicolumn{2}{|c|}{$\begin{array}{c}\text { Partial } \\
\text { comprehension }\end{array}$} & \multicolumn{2}{|c|}{$\begin{array}{l}\text { Incomprehensi } \\
\text { on }\end{array}$} & \multicolumn{2}{|c|}{$\begin{array}{l}\text { Mis-comprehe } \\
\text { nsion }\end{array}$} & \multicolumn{2}{|c|}{ No response } \\
\hline & $f$ & $\%$ & $f$ & $\%$ & $f$ & $\%$ & $f$ & $\%$ & $f$ & $\%$ \\
\hline 1. Content & 9 & 7,9 & 52 & 45,6 & 30 & 26,3 & 4 & 3,5 & 19 & 16,6 \\
\hline 2. Unit & 30 & 26,3 & 42 & 36,8 & 17 & 14,9 & 5 & 4,3 & 20 & 17,5 \\
\hline
\end{tabular}

In order to determine the level of comprehension the "content" concept of the teacher candidates participating in the study, the question "What is the content?" was asked. As a result of the analysis; $45.6 \%$ have answered in the level of partial comprehension, $26.3 \%$ of them with incomprehension, $9 \%$ of them with comprehension, 3.5\% of them with miscomprehension. $16,6 \%$ of the participants did not answer this question. Examples of teacher candidates' responses at a limited level of comprehension include: "sum of information", "details of a topic", "information to be given to the student", "the whole of the information that constitutes the subject", "the whole of the subject", "information to be given", "subjects to be taught", "information on one lesson", "information society". Some of the responses of prospective teachers at the level of comprehension are: "all the goals of a lesson", "a broad perspective", "everything in the lesson", "detail", "content of the subject", "the essence to be told in the subject", "main title", "the main idea", "the whole of the elements that make up a process", "the part that makes up for something". 
Analysis of answers given to the question "What a unit is?" show that $36.8 \%$ participants' answers are in the level of partial comprehension, $26.3 \%$ of them are at comprehension, $14.9 \%$ of them with incomprehension, $4.3 \%$ of them are at miscomprehension level. $17.5 \%$ of the teacher candidates could not answer this question. Examples of students' responses at a partial comprehension include: "common theme of similar talents", "the separation of the course by subject", "parts of the course", "parts of the book", "the main community", "title of similar gains", "separation of topics". Some of the answers of the teacher candidates at the level of miscomprehension are: "topics to be handled", "sub-learning field", "the convergence of similar disciplines" and "the integration of themes".

\subsection{Level of Comprehension of the Concepts of the Curriculum Related to the Dimension of Learning-Teaching Process}

In order to determine the level of comprehension the concepts of "readiness", "lack of learning", "learning difficulty", "cognitive development", "affective development", "motional development", "individual difference" and "performance" the questions were directed to participants and findings are presented in Table 4 below:

Table 4. Participants levels of comprehension about concepts of teaching and learning component of the curriculum

\begin{tabular}{|c|c|c|c|c|c|c|c|c|c|c|}
\hline \multirow[t]{2}{*}{ Concepts } & \multicolumn{2}{|c|}{ Comprehension } & \multicolumn{2}{|c|}{$\begin{array}{c}\text { Partial } \\
\text { comprehension }\end{array}$} & \multicolumn{2}{|c|}{ Incomprehension } & \multicolumn{2}{|c|}{ Mis-comprehension } & \multicolumn{2}{|c|}{$\begin{array}{c}\text { No } \\
\text { response }\end{array}$} \\
\hline & & & $f$ & $\%$ & $f$ & $\%$ & $f$ & $\%$ & $f$ & $\%$ \\
\hline 1. readiness & 26 & 22,8 & 48 & 42,1 & 23 & 20,1 & 14 & 12,2 & 3 & 2,6 \\
\hline 2. limited learning & 27 & 23,6 & 50 & 43,8 & 14 & 12,2 & 6 & 5,2 & 17 & 14,9 \\
\hline 3. learning difficulty & 28 & 24,5 & 55 & 48,2 & 16 & 14,0 & 8 & 7,0 & 7 & 6,1 \\
\hline 4. cognitive development & 13 & 11,4 & 47 & 41,2 & 36 & 31,5 & 6 & 5,2 & 12 & 10,5 \\
\hline 5. affective development & 15 & 13,1 & 44 & 38,6 & 36 & 31,5 & - & - & 19 & 16,6 \\
\hline 6. psycho-motor development & 23 & 20,1 & 41 & 35,9 & 35 & 30,7 & - & - & 15 & 13,1 \\
\hline 7. individual difference & 55 & 48,2 & 43 & 37,7 & 15 & 13,1 & - & - & 1 & 0,8 \\
\hline 8. performance & 17 & 14,9 & 45 & 39,4 & 28 & 24,5 & 10 & 8,7 & 14 & 12,2 \\
\hline
\end{tabular}

Results of the analysis show that regarding to the concept of "readiness" $42.1 \%$ of the participants answered in the level of partial comprehension, $22.8 \%$ of them with comprehension, $20.1 \%$ of them with incomprehension and $12.2 \%$ of them with miscomprehension. $2.6 \%$ of the teacher candidates could not answer this question. Examples of students' responses at a partial level of comprehension include: "to be adequate", "to come to the level of learning to write", "previously gained characteristic", "having a prior opinion on a topic", "having preliminary experiences". Some of the answers of teacher candidates at the miscomprehension level are: "access to maturity", "availability status", "willingness to learn", "the desire to learn behaviour or achievement", "talent", "the best way and time to learn", "what the individual intentionally did".

As to concept of "limited learning", $43.8 \%$ of student teachers answered in the level of partial comprehension, $23.6 \%$ of them with comprehension, $12.2 \%$ of them with incomprehension and $5.2 \%$ of them with miscomprehension. $14.9 \%$ of the teacher candidates gave no answer to this question. Examples of students' responses at a partial level of comprehension include; "not getting the gains at the desired level", "incomplete acquisition of gains", "an incomplete learning of a topic", "not learned", "not occurring of permanent behaviour", "unlearned achievement", "not having sufficient knowledge". Some of the teacher candidates' answers at the miscomprehension level are: "mentally unable to understand things", "late comprehension", "giving incomplete information".

As to the concept of "learning difficulty"; $48.2 \%$ of the participants answered in the level of partial comprehension, $24.5 \%$ of them with comprehension, $14 \%$ of them with incomprehension and $7.0 \%$ of them with miscomprehension. $6.1 \%$ of the teacher candidates could not answer this question. Examples of students' responses at a partial level of comprehension include: "unable to gather attention", "learning very slow", "difficult and late learning", "realization of learning in a longer period than it is", "difficulty in learning", "not comprehension of some things", "late comprehension", "disruption to learning", "not being able to understand". Some of the answers of the teacher candidates at the level of miscomprehension are: "being left behind the class", "difference in learning", "unearned learning", "learning speed".

As to the concept of "cognitive development"; $41 \%$ of the participants answered in the level of partial comprehension, $31.5 \%$ of them with incomprehension, $11.4 \%$ of them with comprehension and 5.2\% of them with miscomprehension. $10.5 \%$ of the teacher candidates could not answer this question. Examples of students' responses at a partial level of comprehension include: "development occurred in the mind", "development related to knowing, comprehension and analysis", "to analyse information", "mentally interpretation of information", "mental learning", "improvement in knowledge level", "the development of mental functions", "change process in the mind". Some of the answers of teacher candidates at the level of incomprehension are; "comprehension of information", "mental development", "the development of intelligence", "change in the direction of knowledge", "everything about information", "academic information", "mental self-improvement", "the improvement of the level of knowledge". 
In regard to the concept of "affective development"; $38.6 \%$ of the participants responded in the level of partial comprehension, $31.5 \%$ of them with incomprehension and $13.1 \%$ of them with comprehension. $16,6 \%$ of the teacher candidates could not answer this question. Examples of students' responses at a partial level of comprehension include: "being at the desired level in terms of feelings and thoughts", "the development of the individual in emotional sense", "progress in the sense of emotion and thought". Some of the answers of the teacher candidates at the level of incomprehension are; "development of sense organs", "emotionally, to be more sensitive", "psychological maturity", "being respectful", "to take the sense organs to learning", "addressing sensory organs", "development in sensory organs", "the child's emotional development", "about feelings".

In regard to the concept of "pyscho-motor development"; $35.9 \%$ of participant teacher candidates answered in the level of partial comprehension, $30.7 \%$ of them with incomprehension and $20.1 \%$ of them with comprehension level. $13,1 \%$ of the teacher candidates could not answer this question. Examples of students' responses at a partial level of comprehension include: "the development of motor skills", "development of fine motor muscles", "able to do psychomotor behaviours", "able to do psychomotor skills". Some of the answers of the prospective teachers at incomprehension level are as follows: "hand eye co-ordination", "physical development", "psychomotor skills", "physical development", "kinaesthetic behaviour".

As to the concept of "individual difference"; $48.2 \%$ of the participants answered in the level of comprehension, $37.7 \%$ of them with partial comprehension and $13.1 \%$ of them with incomprehension. $0,8 \%$ of the teacher candidates could not answer this question. Examples of students' responses at a partial level of comprehension include: "the differences between individuals in terms of emotion, thought and skill", "being different of the interests and needs of each student from each other in terms of their abilities", "having different intelligence areas and different developmental characteristics of each individual", "being different of the people in terms of cognitive, affective and psychomotor development", "uniqueness and speciality of each student", "being different of the people from one another in terms of interest, attitude, intelligence". Some of the answers of the teacher candidates at the level of incomprehension are; "differences between peers", "every individual is responsible for him/herself", "comprehension achievements at different levels", "varies from person to person", "differences in terms of religion, language and race", "differences arising from needs", "everyone is not the same".

As to the concept of "performance" within the category of teaching and learning process, $39.4 \%$ of them answered in the level of partial comprehension, $14.9 \%$ comprehension, $24.5 \%$ of them with incomprehension, $8.7 \%$ of them with miscomprehension. $12.2 \%$ of the teacher candidates gave no answer to this question. Examples of responses at a partial level of comprehension include: "The effort shown in a job", "the effort spent in a situation", "the effort spent in doing a job", "the maximum level shown in the skill", "the display of the learning situation", "the level of success demonstrated". Some of the answers of teacher candidates at the miscomprehension level are; "spent energy", "desire", "self-realization", "tasks and responsibilities", "the level of motivation that the individual has shown", "change in behaviour", "being active", "the highest attitude and behaviour exhibited by the individual".

\subsection{Level of Comprehension of Concepts Related to the Assessment Component of the Curriculum}

In order to determine the level of comprehension the concepts of "measurement", "evaluation", "summative assessment" and "formative assessment" of the classroom teachers participating in the study, the questions were directed and findings are summarized in Table 5 below.

Table 5. Levels of comprehension the basic concepts of the assessment component of the curriculum

\begin{tabular}{|c|c|c|c|c|c|c|c|c|c|c|}
\hline \multirow[t]{2}{*}{ Concepts } & \multicolumn{2}{|c|}{ Comprehension } & \multicolumn{2}{|c|}{$\begin{array}{l}\text { Partial } \\
\text { comprehension }\end{array}$} & \multirow{2}{*}{$\begin{array}{c}\text { Incomprehension } \\
f f\end{array}$} & \multicolumn{4}{|c|}{ Mis-comprehension } & \multirow{2}{*}{$\begin{array}{c}\text { No } \\
\text { response } \\
\%\end{array}$} \\
\hline & $f$ & $\%$ & $f$ & $\%$ & & $\%$ & $f$ & $\%$ & $f$ & \\
\hline 1. Measurement & 53 & 46,4 & 28 & 24,5 & 17 & 14,9 & 10 & 8,7 & 6 & 5,2 \\
\hline 2.Evaluation & 54 & 47,3 & 26 & 22,8 & 14 & 12,2 & 15 & 13,1 & 5 & 4,3 \\
\hline $\begin{array}{l}\text { 3.Summative } \\
\text { assessment }\end{array}$ & 35 & 30,7 & 46 & 40,3 & 14 & 12,2 & 8 & 7,0 & 11 & 9,6 \\
\hline 4.Formative assessment & 46 & 40,3 & 49 & 42,9 & 10 & 8,7 & 11 & 9,6 & 9 & 7,8 \\
\hline
\end{tabular}

As shown in Table 5, as a result of the analysis of the answers given by the class teacher candidates participating in the study to the questions asked about the level of comprehension the concept of "measurement", $24.5 \%$ of them gave answers at partial comprehension, $14.9 \%$ of them with incomprehension, $8.7 \%$ of them at miscomprehension levels. $5.2 \%$ of the teacher candidates could not answer this question. Examples of students' answers at comprehension level are as follows: "to express the quantity to be measured with numbers and symbols", "expressing the observations with numbers and symbols", "to determine whether there is a certain characteristic in a person or object, if so, in what level is it, with the help of certain tools". Some of the answers of teacher candidates at the level of miscomprehension are: 
"the process of evaluating all the learnings as a criterion", "evaluating knowledge, skills and behaviours", "proving", "criterion to be used in the course evaluation".

As to the concept of "evaluation" $47.3 \%$ of the respondents answered in the level of comprehension, $22.8 \%$ of them with partial comprehension, $12.2 \%$ of them with incomprehension and $13.1 \%$ of them with miscomprehension. $4,3 \%$ of the teacher candidates could not answer this question. Examples of students' answers at comprehension level are as follows; "the process of comparing a measurement result with a criterion and reaching a decision", "interpretation of measurement results according to a certain criterion". Some of the answers of teacher candidates at the miscomprehension level are; "the conclusion part of testing living beings", "measuring readiness", "attained status of behaviour", "measurements made for grading", "criterion expressed in the measurement result".

In regard to the concept of "summative assessment", $40.3 \%$ of them answered in the level of partial comprehension, $30.7 \%$ of the candidate teachers answered this question at the level of comprehension, $12.2 \%$ of them with incomprehension, and $7 \%$ with miscomprehension. 9,6\% of the teacher candidates could not answer this question. Examples of students' responses at comprehension level include; "product-oriented measurement", "evaluation of the product at the end of the process", "result-based measurement", "independent evaluation of the product from the process", "evaluation by looking examinations". Some of the answers of teacher candidates at the miscomprehension level are: "commenting on material", "education on concrete objects", "measuring long-term activities".

Finally, as to the concept of "formative assessment" $42.9 \%$ of the participant teacher candidates answered in the level of partial comprehension, $40.3 \%$ of them with comprehension, $8.7 \%$ of them with not comprehension, $9.6 \%$ of them with miscomprehension. $7.8 \%$ of the teacher candidates gave no answer to this question. Examples of students' responses at a partial comprehension level include; "making a measurement while teaching", "evaluating student's activities and projects", "evaluating product steps", "performance evaluation", "measuring the behaviour in the course". Some of the answers of teacher candidates at the level of miscomprehension are "measuring for completeness", "measuring at the end of the unit", "measuring within a certain time frame".

\section{Discussion, Conclusion and Recommendation}

In this study, the level of comprehension of some basic concepts in the Life Science curriculum of the fourth-grade teacher candidates who are studying at the Primary Teacher Education programme is examined. When the field related to the topic is reviewed, it is seen that there are not many studies about the curriculum literacy of the teacher candidates. There are some studies which intended to examine the concepts of measurement and evaluation of teacher candidates. For example; while Arık (2006) identified what are the misconceptions in the field of measurement and evaluation of primary school teachers, in the studies Üztemur (2013), Üztemur and Metin (2015), Akpınar and Kasım (2016) have revealed their conceptual misconceptions and self-sufficiency beliefs in the field of measurement and evaluation. Demirbilek (2015) examined the level of misconceptions in the measurement and assessment course of the teacher candidates in his work. Apart from a few studies carried out to determine the misconceptions in the field of measurement and evaluation, it is thought that no studies have been conducted on the level of comprehension the basic concepts primary curriculum with teachers or teacher candidates. Teachers, on the other hand, serve as a bridge between the curriculum and the students (Jadhav and Patankar, 2013). In particular, it is very important for the teacher candidates to be trained in correct comprehension of the curriculum in the teacher training programs in terms of their ability to practice the curriculum in the future. Teachers' attitudes, skills and motivations play a crucial role in the application of the curriculum (Altrichter, 2005). In this sense, the clear comprehension of the meaning of the curriculum by teachers will also remove the uncertainty between the curriculum and the teaching (Oliva and Gordon, 2018).

In order to determine the level of comprehension of the basic concepts of the life science curriculum in the scope of the research, questions related to the curriculum's "aims and objectives", "content", "learning-teaching process" and "assessment" components were asked to the teacher candidates. In the scope of the "aims and objectives dimension" which is the first of the basic concepts in the curriculum, concepts of "aim", "achievement", "knowledge acquisition " and "attitude acquisition" were asked to primary school teacher candidates. It was found that the teacher candidates have more limited meanings about the concepts other than the concept of "achievement". The concepts of "content" and "unit" were asked in the curriculum for elementary school teacher candidates in the context of the "content" dimension which is the second of the basic concepts. In response to the questions, classroom teacher candidates came to the conclusion that they had a limited meaning in the concept of "content" and "unit". It is seen that classroom teacher candidates were more likely to respond with partial comprehension to the concepts of "readiness", "lack of learning", "learning difficulty", "cognitive development", "affective development", "psycho-motor development", "individual difference" which takes place in the curriculum in the scope of the "learning-teaching process" component. In his study which is titled "the analysis of professional needs of joint class teachers" Sezer (2010) has identified that classroom teachers have variety of needs in in curriculum literacy and assessment. Hakan et al. (2011) found that teachers' 
knowledge of curriculum is rather low. The findings obtained in both studies are in parallel with the findings obtained in this study. The concepts of "measurement", "evaluation", "summative assessment" and "formative assessment" were asked to determine the levels of comprehension the concepts in the dimension of "assessment". Classroom teacher candidates seem to have a partial comprehension in the concept of "summative assessment", while in other concepts they reach the outcome of meaningful learning. In the study that Arik conducted with primary school teachers in (2006), it was revealed that the classroom teachers are the least misguided teachers in the concepts of assessment and evaluation, while the teachers with the highest misconceptions are the teachers of Social Studies and Turkish.

As a result, it was found that the teacher candidates had limited knowledge about the concepts of aims and objectives, content and teaching-learning from the basic concepts in the Life Science curriculum, while they were found to have meaningful learning about the assessment dimension of the curriculum. The fact that classroom teacher candidates have limited knowledge and conceptual misconceptions about the basic concepts of the Life Science teaching curriculum is a clear indication that the teacher candidates have not developed themselves sufficiently in this regard and have not conducted reading and research that have increased their teaching knowledge. It is extremely important that classroom teacher candidates know correctly the concepts of classroom teacher candidates because they know the basic concepts that are included in the life science teaching curriculum either limitedly or incompletely and will cause problems during the implementation of the curriculum.

Based on the results obtained from this research, some suggestions were made as follows;

- In order to increase curriculum literacy for elementary school teacher candidates, basic information about concepts in the Life Science teaching curriculum can be acquired in depth, not superficial.

- In curriculum-literacy activities for classroom teacher candidates, concepts need to be taught in a more concrete way (for example, by developing concept maps, mind and information maps) rather than just being verbalized.

- In addition, instead of memorizing the concepts in the curriculum itself, it should be taught to the teacher candidates by application-based instructional designs how and what the relations between the concepts are in the way of thinking that the curriculum is whole.

- As classroom teacher candidates have misconceptions about the concepts in the life science curriculum, they can get feedback from the teacher candidates during the teaching, and the misunderstandings can be detected and studies can be done to solve this situation.

- Memorization can be avoided during teaching; the basic concepts and principles can be given scientifically to the classroom teacher candidates as they are accepted correctly.

- The classroom teacher candidates can read and do some research projects in order to increase their knowledge about the concepts, in-service training courses can be taken to correct missing and erroneous information about concepts when they become teachers.

- Qualitative and quantitative studies can be carried out using different measurement and evaluation tools for other subject specialist teachers and concepts in other subject areas.

\section{References}

Adigüzel, A. (2009). The problems encountered during the application of the new primary education program, Mehmet Akif Ersoy University Education Faculty Journal, 9(17), 77-94.

Akbaş, Y. (2008). The effect of conceptual change approach to eliminate 9th grade high school students? misconceptions about climate subject. [Published Doctoral Thesis] Atatürk University, Social Sciences Institute, Erzurum.

Akpınar, B. (2011). Eğitim Programlart ve Öğretim (Curriculum and Teaching). Ankara: Data Publishing

Akpınar, M., \& Kasım, Ş. (2016). Determination of Self-efficacy beliefs and misconceptions of Social Science Teachers about alternative measurement and assessment, International Symposium on Social Studies Education, Denizli, 565-575.

Altrichter, H. (2005). Curriculum implementation - limiting and facilitating factors. Internet source: https://s3.amazonaws.com/academia.edu.documents/33186220/curriculum_imp_1.pdf?AWSAccessKeyId=AKIAI WOWYYGZ2Y53UL3A\&Expires=1532114243\&Signature=bh3n\%2F1GQOdroSti\%2B6xbUNc6DcF4\%3D\&res ponse-content-disposition=inline\%3B\%20filename\%3DChapter_2_Curriculum_implementation_limi.pdf Accessed on: 27.05.2018

Altunya, N. (2003). Vatandaşlık bilgisi. (Knowledge of Citizenship), Ankara: Nobel Publishing.

Alvior, M. (2015). The meaning and importance of curriculum development.


https://www.linkedin.com/pulse/meaning-importance-curriculum -development. Date of access: 18.04.2018

Arık, S. R. (2006). Determination of Misconceptions of Primary School Teachersin the Field of Measurement and Evaluation., Unpublished Master's Thesis. Ankara University Educational Sciences Institute, Ankara.

Baki, A. (1999). Evaluation of Operational Misconception about Algorithm. III. Science Education Symposium. Ministry of National Education ÖYGM.

Bennie, K., \& Newstead, K. (1999). Obstacles to implementing a new curriculum. In M.J. Smit and A.S. Jordan (Eds.), Proceedings of the National Subject Didactics Symposium (pp. 150-157). Stellenbosch: University of Stellenbosch.

Büyükkaragöz, S. (1997). Program Geliştirme Kaynak ve Metinler. (Curriculum Development, Sources and texts) Konya: Kuzucular Ofset.

Çepni, S. (2009). Araştırma ve Proje Çalışmalarına Giriş (Introduction to Research and Project Studies) (4 ${ }^{\text {th }}$ edition). Trabzon: Celepler Publishing.

Coşkun, M. K. (2011). Kavram Öğretimi (Teaching Concepts). Seyhan-Adana: Karahan Bookshop

Çüçen, A. K. (1999). Mantık.(Logic) (2. Baskı). Bursa: Asa Bookshop.

Demir, Ö., \& Acar, M. (1992). Sosyal Bilimler Sözlüğü (Dictionary of Social Sciences). İstanbul: Ağaç Publishing

Demirbilek, S. (2015). Examination of pre - service teachers misconceptions in measurement and evaluation concepts. Unpublished Master's thesis. Hacettepe University, Ankara

Demirel, Ö. (1998). Kuramdan Uygulamaya Eğitimde Program Geliştirme (From Theory to Practice Curriculum Development in Education). Ankara: Pegem Academy.

Duman, E. (2006). Determination of curriculum development qualifications of classroom teacher candidates (Samples of Ankara and Kırıkkale Universities). Unpublished Doctoral thesis. Ankara University, Ankara.

Ekiz, D. (2009). Bilimsel Araştırma Yöntemleri (Scientific Research Methods). Ankara: Anı Publishing

Ekiz, D., \& Akbaş, Y. (2005). Primary school 6th grade students' understanding level of conceptions related to astronomy and misconceptions. Milli Eğitim Journal, 165, 61-78.

Fidan, N. (1985). Okulda Öğrenme ve Ögretme.(Learning and Teaching in School), Ankara: Alkım Publishing.

Fullan, M. (2007). The New Meaning of Educational Change. New York: Routledge

Gömleksiz, M. N. (2007). An evaluation of teachers' perceptions of the new primary school curriculum in terms of some variables. Eurasian Journal of Educational Research (EJER), (27). 69-82.

Guiraud, P. (1999). “Semantics”, Multilingual Translator; Vardar, Berke; İstanbul

Güleryüz, H. (2013). Hayat Bilgisi Programlarl ve Öğretimi (Life Science Curriculum and Teaching). (Ankara: Edge Academy

Gür, S. B., \& Çelik, Z. (2009). Türkiye'de Milli Eğitim Sistemi. Yapısal Sorunlar ve Öneriler. (National Education System in Turkey: Structural Problems and Suggestions), SETA Report. URL: https://www.setav.org/turkiyede-milli-egitim-sistemi-yapisal-sorunlar-ve-oneriler/ Retrieved on: 05.05.2018.

Hakan, A., Sağlam, M., Yaşar, Ş., Gültekin, M., Deveci, H., Yapıcıoğlu, D., ... Kasa, B. (2011). In-service needs of Primary school teachers regarding general competencies in teaching profession, Eskişehir: Anadolu University Publishing. No:2215.

İlbi, Ö. (2006). The comparison of education methods computer assisted learning and Ausubel's expository teaching in preventing of misconceptions on chemistry units, Unpublished Doctoral Thesis, Dokuz Eylül University, Educational Sciences Institute, İzmir.

Jadhav, M., \& Patankar, P. (2013). Role of Teachers' in Curriculum Development for Teacher Education. Paper presented at National Conference on Challenges in Teacher Education, Physical Education and Sports, At Kolhapur, Maharashtra, India, 18-19 October.

Karacaoğlu, Ö. C., \& Acar, E. (2010). The issues that teachers encounter during application of new curricula, Yüzüncü Yll University, Education Faculty Journal, 7(1), 45-58.

Malatyal1, E., \& Y1lmaz, K. (2010). The importance of concepts in the constructivist learning process: an examination of concepts from pedagogical angle, International Social Researches Journal, 3(14), 320-332.

Marsh, C. J. (2009). Key Concepts for Comprehension Curriculum, (4th Edition), Oxon, UK:Routledge 
MEB. (2017). Öğretmenlik Mesleği Genel Yeterlikleri. (General Qualifications of Teaching Profession), Ankara: General Directorate of Teacher Training and Development.

Murphy, G. L. (2002). The big book of concepts. London, England: The MIT Press.

Nakhleh, M. B. (1992). Why some Students don’t Learn Chemistry. Journal of Chemical Education, 69, 191-196.

Oliva, P. F., \& Gordon, W. R. (2018) Program Geliştirme (Curriculum Development), (8th Edition Translation, Editor, Gündoğdu, K.), Ankara: PegemA Publishing

Özçelik, D. A. (1992). Eğitim Programları ve Öğretim. (Curriculum and Teaching), Ankara. ÖSYM Publishing

Penuel, W. R., Phillips, R. S., \& Harris, C. J. (2014). Analyzing teachers' curriculum implementation from integrity and actor-oriented perspectives. Journal of Curriculum Studies, 46(6), 751-777.

Senemoğlu, N. (2005). Gelişim Öğrenme ve Öğretim Kuramdan Uygulamaya, (Development, Learning and Teaching: From Theory to Practice), Ankara: Gazi Publishing, 12th Edition.

Sezer, R. (2010). Analysis of the professional needs of a class teacher teaching in multigrade classes, Unpublished Doctoral Thesis, Mehmet Akif Ersoy University Social Sciences Institute, Burdur.

Shulman, L. S. (1987). Knowledge and teaching: Foundations of the new reform. Harvard Educational Review, 57(1), 61-77.

Stabback, P. (2016). What Makes a Quality Curriculum? In-Progress Reflection No. 2 on" Current and Critical Issues in Curriculum and Learning". UNESCO International Bureau of Education.

Stein, M. K., \& Coburn, C. E. (2008). Architectures of learning: A comparative analysis of two urban school districts. Center for the Study of Teaching and Policy, University of Washington.

TDK, (2016). Bilim ve Sanat Terimleri Sözlüğ̈̈. (Dictionary of Science and Arts Terminology), http://tdk.gov.tr/index Retrieved on: 1st March 2016

Temizkan, M. (2008). An evaluation on the attitudes of Turkish teacher candidates their professions, The Journal of Turkish Educational Sciences, 6(3), 481-486.

Ülgen, G. (2004). Kavram gelişstirme kuramlar ve uygulamalar. (Theories and practices in concept development), $\left(4^{\text {th }}\right.$ Edition). Ankara: Nobel Publishing.

Üztemur, S. S., \& Metin, C. (2015). Examining social studies teachers' misconceptions in assessment and evaluation and their self- efficacy beliefs. Anatolian Journal of Educational Leadership and Instruction, 3(2), 41-67.

Varış, F. (1996). Eğitimde Program Geliștirme. Teori ve Teknikler. (Curriculum Development: Theory and Techniques), Ankara: Alkım Publishing.

Yıldırım, A., \& Şimşek, H. (2011). Sosyal Bilimlerde Nitel Araştırma Yöntemleri. (Qualitative Research Methods in Social Sciences), Ankara: Seçkin Publishing.

Yüksel, S. (1998). Participation of teachers in curriculum development, Educational Administration: Theory and Practice 4(1), 99-106.

\section{Copyrights}

Copyright for this article is retained by the author(s), with first publication rights granted to the journal.

This is an open-access article distributed under the terms and conditions of the Creative Commons Attribution license which permits unrestricted use, distribution, and reproduction in any medium, provided the original work is properly cited. 